\title{
RESIDENTIAL LANDSCAPING IN PHOENIX, ARIZONA, U.S.: PRACTICES AND PREFERENCES RELATIVE TO COVENANTS, CODES, AND RESTRICTIONS
}

\author{
by Chris A. Martin', Kathleen A. Peterson', and Linda B. Stabler ${ }^{1}$
}

\begin{abstract}
In the Phoenix, Arizona, U.S., metropolitan area, community associations with legally binding covenants, codes, and restrictions (CC\&Rs) impose limitations on landscaping activities in many new neighborhood residential communities. Studies were conducted in the Phoenix area to develop an understanding of residential homeowner landscape preferences and practices and how they might be impacted by CC\&Rs. Residential yards in communities with CC\&Rs controlling landscape activity had fewer trees, more shrubs and groundcovers, and less turf coverage than did landscapes in communities without CC\&Rs. More homeowners identified their front yard landscapes as being a desert design type rather than an oasis or mesic design, with the percentage higher for homeowners living in neighborhoods with CC\&Rs than for those in neighborhoods without CC\&Rs. More homeowners preferred an oasis landscape design type to either desert or mesic designs, and roughly $70 \%$ of homeowners preferred a landscape design type that had at least some lawn area. More Arizona natives preferred mesic landscapes than did domestic migrants. Homeowners cited ease of maintenance and landscape aesthetics as the two most important traits for their landscape. These findings reflect the increasing influence and importance of desert landscape design in the U.S. Southwest as a contemporary landscape design style in urban areas bridled by an arid climate and suggests that the emergent popularity of desert landscaping in Phoenix is predominately a top-down social phenomenon directed by public and private interest groups for residential homeowner use.
\end{abstract}

Key Words. Human issues; landscape design; landscape ordinances; plant diversity.

More than $80 \%$ of people in the United States now live in cities (U.S. Census Bureau 2002a). Cityscapes are unique among the world's ecosystems in their intense domination by people. Cities in the United States have unique assemblages of landscape vegetation that reflect a blending of environmental, socioeconomic, and technological factors (Motloch 1991). This is especially true of Phoenix, Arizona, where the sparse vegetation of the Sonoran Desert has been replaced by irrigated and managed urban landscapes that serve diverse human interests.

Historically, the character of landscape vegetation in Phoenix has been that of an oasis in the desert and has been typified by landscape greenery. Prior to the early 1960s and the advent of air conditioning, Phoenix landscapes were dominated by large shade trees and grassy lawns that cooled the environment through the latent heat of evaporation. Since the late 1980s, municipal policy has shifted away from these mesic landscapes toward advocating water-conserving landscape designs and use of desert-adapted plants because of concerns about the distribution, abundance, and quality of fresh water resources (Martin 2001).

Landscape vegetation confers numerous physical and aesthetic benefits in urban environments (Rowntree and Nowak 1991; Hull 1992). The density of vegetation in residential areas might significantly contribute to variations in urban climate (Martin et al. 2000). Residential landscapes can also provide aesthetic surroundings for human living as well as for wildlife habitat, protection against soil erosion, and microclimate control through shade and windbreaks (McBride 1977; McPherson et al. 1988; McPherson 1998). Though some of these ecological benefits are difficult to quantify, landscape plantings can increase home property values by up to $20 \%$ or more (Hardy et al. 2000) and are a sought-after attribute when individuals consider the purchase of a home (Correll and Knetson 1978; Getz et al. 1982; Anderson and Cordell 1988).

Residential communities constitute the majority of land cover in the Phoenix area (Gober et al. 1998; Fry et al. 2001). Residential landscapes, though largely a human construct, are the main venue through which people come into contact with nature on a daily basis (Niemiera et al. 1993; Garber and Bondari 1995). Some Phoenix residential landscape designs mimic the surrounding Sonoran Desert and are locally called "desert" landscapes. Other landscapes emulate green, mesic environments such as those found in the eastern United States, while still other landscapes have an "oasis" design motif that is a mixture of the two. Since 1985, domestic migration has accounted for more than $56 \%$ of the increase in population in the greater Phoenix area (Arizona State 
University 2001). The extent to which domestic migrants, most coming from areas with wetter climates than Phoenix, consider lush mesic or oasis landscape design motifs more appealing than desert planting themes is unknown.

Residential landscape design is not always under the control of the homeowner in Phoenix. In the last few decades, there has been a widespread trend toward construction of planned communities that are organized and managed by neighborhood community associations. These community associations levy regular fees on neighborhood residents and impose covenants, codes, and restrictions (CC\&Rs) that govern homeowner practices. Most of these CC\&Rs dictate landscape plant materials and control homeowner landscape activities under the rubric of preserving residential community property values. Potential impacts of these $C C \&$ Rs on the structure and composition of residential landscapes, as well as on the landscape perceptions and activities of community residents are unknown.

How residential landscapes are impacted by CC\&Rs is important because the present increased occurrence of communities with CC\&Rs has great potential to alter the future ecology of the urban landscape. We conducted studies of neighborhood homeowner socioeconomic factors and landscape preferences and landscape plant community structure in the greater metropolitan Phoenix area from 1999 through 2000. Our studies were aimed at developing an understanding of homeowner landscape preferences and practices and how they might be impacted by community landscape ordinances. Through our research efforts, we also sought to learn the extent to which CC\&Rs that control urban landscaping practices impact the structure and composition of residential vegetation.

\section{MATERIALS AND METHODS}

Eighteen neighborhood communities in the greater Phoenix metropolitan area with or without CC\&Rs that control homeowner landscape activity were selected for study. The greater Phoenix metropolitan area is situated in the Salt River Valley at the northeastern edge of the Sonoran Desert in the southwestern United States $\left(33^{\circ} \mathrm{N} 112^{\circ} \mathrm{W}\right)$ at an approximate elevation of $335 \mathrm{~m}$. The local climate is arid, with mean annual precipitation of $180 \mathrm{~mm}$. The city of Phoenix has developed on lands that were either formerly agricultural (primarily cropping of citrus, cotton, winter wheat, and corn) or sparsely arrayed with lower Sonoran Desert vegetation (Lower Colorado Valley subdivision) dominated by Larrea tridentata (creosote bush), Parkinsonia florida (blue palo verde), and Olneya tesota (desert ironwood). Almost exclusively, residential landscape vegetation in Phoenix is intentionally planted and irrigated.

The 18 neighborhood communities (nine with CC\&Rs and nine without) were aggregated geographically into four distinct regions of the Phoenix metropolitan area (north, south, east, and west). The average number of homes in each community was 294 , with a range of 34 to 1,376 homes. Only communities developed after 1985 were selected for this study to capture the most accurate representation of current landscape design trends.

\section{Survey Assessment of Residential Socioeconomic Factors and Landscape Practices and Preferences}

A mail survey was developed for residential homeowners with questions asking for information about their landscape practices and preferences. The survey went through two pretests. The first pretest was given to 300 undergraduate students in an introductory plant biology course at Arizona State University. After revision, the second pretest was given to 16 home residents who had participated previously in a research project at Arizona State University and were from neighborhood communities similar to the intended survey participants.

On September 27, 1999, 1,800 surveys were mailed to a random sample of homeowners from each of the 18 residential communities. To lower the nonresponse rates, we included with each survey a detailed cover letter and a self-addressed stamped envelope. A reminder postcard was then mailed to all survey recipients 1 week after the first mailing, and a second complete mailing package was sent 3 weeks after the first survey to any nonrespondents. We considered the survey to be complete after 6 weeks because as reported by others (Dillman 1978), we found that the rate of survey responses dramatically decreased 2 weeks after first contact and virtually stopped 5 weeks after we mailed the reminder postcard.

We obtained residential property data pertaining to home value, size, and ownership from the Maricopa County Tax Assessor (2002). We used these data from 1999 in our statistical analysis. We also used data from the 2000 United States Census (2002b) to make general characterizations about the demographics of Arizona residents.

\section{Assessment of Residential Vegetation Structure and Composition}

A ground study of front yards in the surveyed residential communities was made during the year 2000 following methods described by O'Rourke (1981) to detect any effects of CC\&Rs on the structure and composition of residential landscape vegetation. Because the 18 communities were of disparate size, a minimum of ten, or $10 \%$ of home residences in each community, whichever was the greater number, were randomly selected for study. Front yards were chosen because of ease of accessibility and because CC\&Rs in the Phoenix area typically restrict homeowner landscape activities only in the front yard. To avoid trespassing onto private property, all ground measurements were obtained by observations from the residential street most juxapositioned to the front of each residential yard. Front yards were defined as all pervious landscape surface areas that were in 
front of the house and any on the sides of each house that could be seen from residential streets as part of the front yard. Because most homes in the greater Phoenix area have fences partitioning their property into front yards and backyards, separation of front yards and backyards of homes was easily discernable.

Data collected in front yards included number of trees, shrubs and groundcovers, and turf coverage where present. Landscape vegetation was identified by taxa and compiled by genera for each residential community. Calculations of total plant frequency (no./100 $\mathrm{m}^{2}$ of landscape surface area); frequency of trees, shrubs, and groundcovers; estimations of the cover percentage (0-25\%, 26\%-50\%, $5 \%-75 \%, 76 \%-100 \%$ ) of turfgrass; and genera richness (no./100 $\mathrm{m}^{2}$ of landscape surface area) in each yard were made. For trees, a Sorenson's beta diversity index was calculated to compare the similarity of genera within the 18 communities.

\section{Data Analysis}

Survey data were organized and analyzed using a 2 (with and without CC\&Rs) by 4 (north, east, south, and west location in the city) factorial unbalanced experimental design approach. First, all survey data were hand-entered into a Microsoft Access '97 (Microsoft Corp., Redmond, WA) relational database. For landscape genera composition and diversity data from each community, Sorenson's beta diversity indices for tree genera similarity were used in an average linkage cluster analysis to develop relationships of landscape tree genera diversity among communities. For all other data, treatment comparisons were made using a general linear model or factor procedure (SAS version 6.03, SAS Inst., Cary, NC). Pearson's correlation coefficients $(r)$ were calculated to determine the measure of the degree of association between response variables using Statview ${ }^{\circledR} 5$ (SAS Inst., Cary, NC). Comparison of treatment means was made using the Tukey-Kramer method. The level of significance was set at $\alpha=0.05$.

\section{RESULTS AND DISCUSSION Residential Landscape Structure}

We found that in the Phoenix metropolitan area, CC\&Rs that control landscape activities affected the structure of residential landscape vegetation, regardless of geographic location in the city (Table 1). Landscapes in neighborhood communities with CC\&Rs had fewer trees, more shrubs and groundcovers, and less turf coverage than did landscapes in communities without CC\&Rs. Some possible ramifications of fewer trees in neighborhood communities with CC\&Rs might be a reduction in urban forest carbon storage potential (Martin and Stabler 2002; Nowak et al. 2002), higher energy costs for residential home cooling due to decreased shading (McPherson et al. 1993; McPherson 1994), and ultimately a facilitation of
Table 1. Effect of residential community landscape covenants, codes, and restrictions (CC\&Rs) on frequency of occurrence and genera richness of landscape plants in residential landscapes in the Phoenix, Arizona, metropolitan area.

\begin{tabular}{|c|c|c|}
\hline Frequency and genera richness & CCERs & No CC\&Rs \\
\hline Total plant (no./100 $\mathrm{m}^{2}$ ) & $15.7 \mathrm{a}^{*}$ & $13.0 \mathrm{~b}$ \\
\hline Trees (no./100 m²) & $1.8 \mathrm{~b}$ & $2.3 \mathrm{a}$ \\
\hline Shrubs (no./100 m²) & $10.5 \mathrm{a}$ & $7.9 \mathrm{~b}$ \\
\hline Groundcovers (no./100m²) & $7.2 \mathrm{a}$ & $3.9 \mathrm{~b}$ \\
\hline Turf (\% total surface cover) & $31 \%$ & $44 \%$ \\
\hline Genera richness (no./100 m²) & $5.8 \mathrm{a}$ & $4.9 \mathrm{a}$ \\
\hline
\end{tabular}

"Mean values in rows followed by the same letter are not significantly different, Tukey-Kramer, $\alpha=0.5$.

elevated summer nighttime temperatures associated with the Phoenix urban heat island (Martin et al. 2000). Though landscape structure was different, we found no difference between communities with or without CC\&Rs in terms of plant genera richness.

The cluster analysis of the similarity in tree genera for individual neighborhood communities in the Phoenix metropolitan area showed that there were two cluster groups (shown as cluster A and B) of five residential communities that had similarities of tree taxa greater than $65 \%$ (Figure 1). Though neighborhood communities in cluster B appeared to group together geographically in the north and west parts of the Phoenix metropolitan area, there was otherwise no apparent relationship between similarities in tree taxa and whether communities had, or did not have, CC\&Rs. Common taxa in cluster A included Acacia, Brachychiton, Ficus, Syagrus, Prosopis, and Washingtonia. Common taxa in cluster B included Acacia, Ficus, Fraxinus, Jacaranda, Parkinsonia, Pinus, and Prosopis.

\section{Survey Demographics}

There were a total of 944 homeowner survey respondents, a slightly higher than 52\% response rate. The response rate of homeowner survey recipients in neighborhood communities with CC\&Rs was $48 \%$ compared with a response rate of $56 \%$ for homeowner recipients in communities without CC\&Rs.

Only 13\% of homeowner survey respondents were born in Arizona, which meant that $87 \%$ of respondents were born elsewhere and subsequently migrated to the Phoenix area to live (Table 2). We found that homeowner respondents from the Southeastern, Great Plains, or Intermountain regions of the United States were most likely to live in neighborhoods with CC\&Rs. In contrast, homeowners originally from the Northeast, Pacific West, Midwest, or Southwest United States, including Arizona natives, were most likely to live in neighborhoods without CC\&Rs. When homeowners were asked how long they had lived in Arizona, 38\% indicated that they had lived in the state less than 5 years, while 32\% indicated they had lived in Arizona between 6 and 15 years. Otherwise, 30\% 


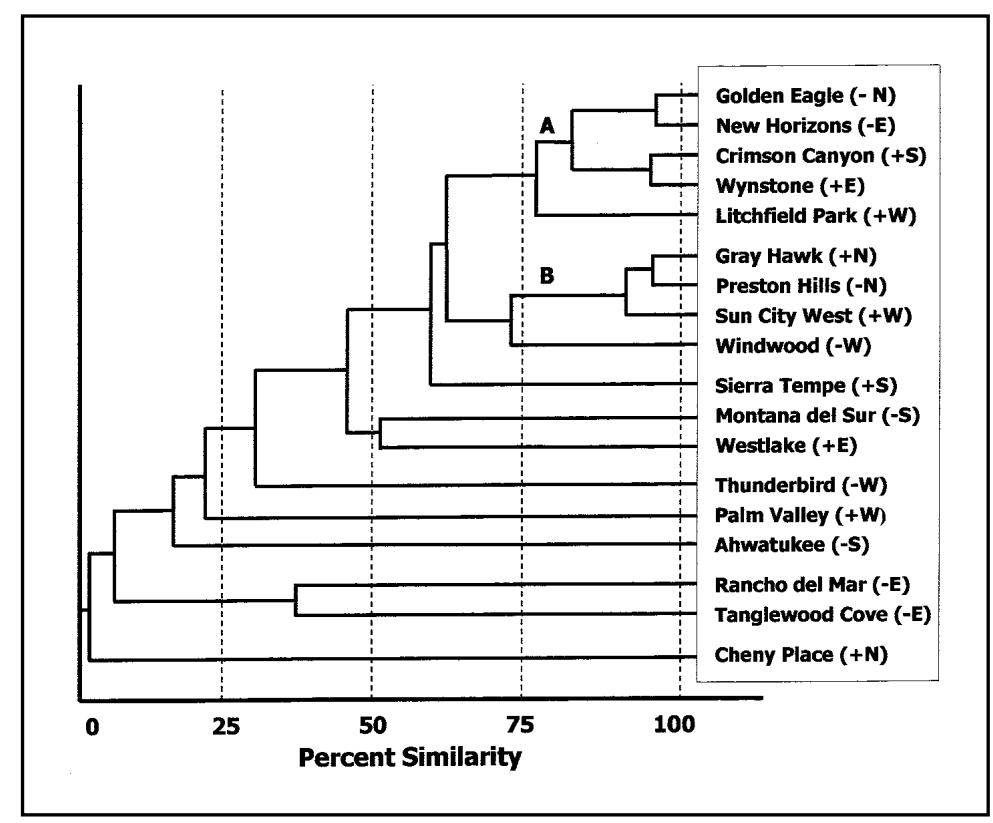

Figure 1. Average link cluster analysis of 18 neighborhood communities in the Phoenix, Arizona, metropolitan area, based on similarity of residential tree taxa. Neighborhood communities are identified by community name; presence (+) or absence $(-)$ of neighborhood covenants, codes, and restrictions (CC\&Rs); and geographic location within the city [N (north), E (east), $S$ (south), and $W$ (west)].

of respondents stated they had lived in the state longer than 15 years, with $12 \%$ of those noting that they had lived in Arizona longer than 25 years.

Homeowner respondents living in neighborhood communities with CC\&Rs had fewer children $(0.77 \pm 0.05$ per household) under the age of 18 than respondents living in communities without CC\&Rs $(1.00 \pm 0.05$ per household). In comparison, the 2000 U.S. Census (2002b) reported an average of 1.37 children under 18 years of age per household in Maricopa County and that the percentage of Maricopa County households with persons under 18 was only $36.2 \%$. In terms of level of education, $78 \%$ of the homeowner respondents indicated that at least one family member had a bachelor's degree. There was no difference in the educational level of respondents living in communities with or without CC\&Rs.

Maricopa County Assessor's data showed that the median 1999 value of survey respondents' homes was \$186,000 in neighborhood communities with CC\&Rs and \$145,000 in communities without CC\&R restrictions (Maricopa County Tax Assessor 2002). Ninety-three percent of all homeowners who responded rated landscape appearance as an important factor when considering the monetary value of their homes, although $81 \%$ of homeowners indicated that they did not take into account the presence or absence of CC\&Rs when choosing to purchase their home. Interestingly, $87 \%$ of homeowners stated that they were happy with their current situation of having, or not having, landscape ordinances in their neighborhood. Of the minority 13\% who were not satisfied with their current conditions, there was disagreement between those who desired more regulation and those who desired less regulation of landscape activities in their neighborhood.

\section{Residential Homeowner Landscape Preferences and Practices}

Homeowners in the Phoenix area and surrounding southwestern United States are increasingly presented with local public campaigns prompting water conservation and the use of desert or dry-land landscape designs to conserve fresh water resources (Arizona Department of Water Resources 2002). However, previous studies have shown that people prefer greenspaces with many textures and colors to open bare landscapes (Kaplan 1984; Rodie and Paprozzi 1999). Our examination of CC\&R documents from neighborhood communities with governing associations showed that those with ordinances that restrict landscape activities typically do so only for front yard and not backyard landscapes. We first asked homeowners to describe their front yard and backyard landscape as having a desert, oasis, or mesic planting design motif (Figure 2). More homeowners responded by identifying their front yard landscapes as being a desert design type rather than an oasis or mesic design, with the percentage doing so being higher for homeowners in communities with CC\&Rs than for those without CC\&Rs (Table 3). The least common front yard design motif reported by homeowners living in either CC\&R or non-CC\&R communities was mesic.

Regardless of the presence or absence of CC\&Rs, more homeowners defined their backyard landscape as being an oasis design type rather than a desert or mesic design (Table 3). A majority (54\%) of homeowners with children had backyards with an oasis design motif, and $81 \%$ of homeowners with children reported having a turfgrass lawn in their backyard. In contrast, the most common (47\%) backyard landscape design type of homeowners without children was a desert design without a lawn, although 53\% of homeowners without children reported having a backyard landscape with a turfgrass lawn as part of either an oasis or mesic landscape design motif.

Homeowners were then asked to express their personal preference for desert, oasis, or mesic landscape design motifs without regard to the types of landscape designs in their own yards. Consistent with the actual design motif found in homeowner back yards, more homeowners preferred an oasis landscape design type than either desert or mesic. There was no difference in this preference for an oasis design between CC\&R or non-CC\&R community residents (Table 3). 
Table 2. Percentage of survey respondents who lived in residential communities with or without covenants, codes, and restrictions (CC\&Rs) in Phoenix, Arizona, metropolitan area, in relation to geographic place of origin in the United States.

\begin{tabular}{lll}
\hline Place of origin* & CC\&Rs & No CC\&Rs \\
\hline Northeast & $47 \%$ & $53 \%$ \\
Southeast & $56 \%$ & $44 \%$ \\
Midwest & $47 \%$ & $53 \%$ \\
Great Plains & $55 \%$ & $45 \%$ \\
Southwest & $39 \%$ & $61 \%$ \\
Intermountain & $59 \%$ & $41 \%$ \\
Pacific West & $43 \%$ & $57 \%$ \\
\hline
\end{tabular}

*Northeast = Delaware, Connecticut, Maine, Maryland, Massachusetts, New Ha mpshire, New York, Pennsylvania, Rhode Island, Vermont; Southeast = Alabama, Arkansas, Florida, Georgia, Kentucky, Louisiana, Mississippi, North Carolina, South Carolina, Tennessee, Virginia, West Virginia; Midwest $=$ Minnesota, Wisconsin, Iowa, Missouri, Illinois, Indiana, Michigan, Ohio; Great Plains = Kansas, North Dakota, South Dakota, Nebraska; Southwest = Arizona, New Mexico, Oklahoma, Texas; Intermountain = Colorado, Idaho, Montana, Nevada, Utah, Wyoming; Pacific West = Alaska, California, Hawaii, Oregon, Washington.

However, homeowners in neighborhood communities with CC\&Rs more often preferred desert landscapes to green landscapes than did homeowners who lived in communities without CC\&Rs (Table 3). Because we included lawn areas as a part of both oasis and mesic design motifs, we found that roughly $70 \%$ of homeowners preferred a landscape design type dominated by the color green that had at least some lawn area. These findings underscore the importance in Phoenix of turfgrass lawns as an important and serviceable element of residential landscapes, especially backyard private areas.

We hypothesized that people relocating to Arizona from less arid climates, such as in the eastern United States, would prefer green landscapes because they are legacies of a former home and because these homeowners are recalcitrant to accept the principles of xeriscape landscape design and desert landscaping that are more popular among long-standing Arizona residents. We tested these hypotheses by determining if homeowner's geographic place of origin and length of Arizona residency had an influence on preferences for desert, oasis, or mesic landscape motifs. Surprisingly, we found that the average length of Arizona residency for homeowners preferring desert, oasis, or mesic landscape designs was $9.2 \pm 0.6$, $11.7 \pm 0.5$, or $10.8 \pm 0.9$ years, respectively. We also found that the lowest percentage of respondents (16\%) who preferred desert landscape themes and the highest percentage of respondents (33\%) who preferred mesic landscape themes were Arizona natives (Table 4).

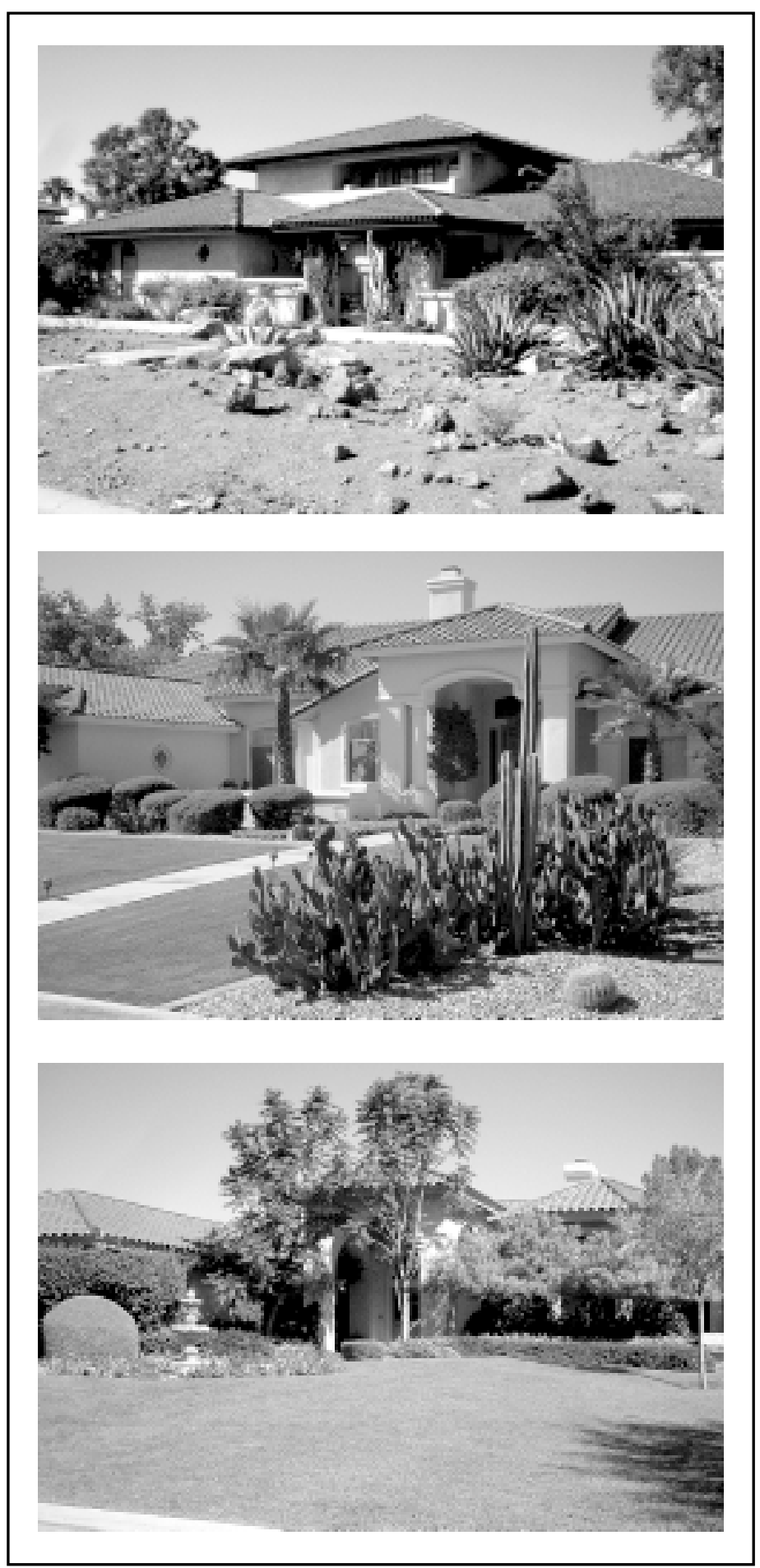

Figure 2. Typical desert (top), oasis (middle), and mesic (bottom) landscape design motifs of residential homes studied in the Phoenix, Arizona, metropolitan area. Images captured by C.A. Martin. 
We then wanted to learn whether restrictions of landscape activities by neighborhood community CC\&Rs on homeowners had any effect on homeowner landscape maintenance activities. We found that those homeowners in neighborhood communities with or without CC\&Rs were equally likely (44\%) to have a flower or vegetable garden. We also found no difference between homeowners living in communities with or without CC\&Rs in the amount of leisure time they spent in their yards. Homeowners reported spending an average of 5.7 hours per week outdoors at leisure in their front or backyards. There was a difference in the amount of time homeowners spent working in the yards. Roughly $67 \%$ of respondents from communities with CC\&Rs did their own landscape maintenance, whereas $75 \%$ of respondents from communities without CC\&Rs did their own landscape maintenance (Table 5). Respondents living in communities with CC\&Rs reported spending about 2.4 hours per week working in their front or back yards, while those living in communities without CC\&Rs reported spending about 3.2 hours per week working in their front or back yards. The median home value of residents who maintained their own yard was $\$ 149,000$, while median home value of residents who employed local landscape firms to maintain their yard was $\$ 201,750$.

Despite the common landscape maintenance practice of formally shearing landscape shrubbery in the Phoenix area, nearly $67 \%$ of all homeowners indicated that they preferred a natural, informal landscape appearance while a little more than one-third of all homeowners indicated a preference for a neat and formal landscape appearance (Table 5). Homeowners were asked to select two landscape traits from a list of the following that they deemed of high importance: (1) ease of

Table 3. Influence of the presence or absence of covenants, codes, and restrictions (CC\&Rs) that control landscape activity on front yard and backyard landscape design motif and home preference for a particular landscape design.

What type of landscape design motif did homeowners actually have?

$\begin{array}{lll}\text { Front yard landscape design } & \text { CC\&Rs } & \text { No CC\&Rs } \\ \text { Desert } & 66 \% & 50 \% \\ \text { Oasis } & 22 \% & 29 \% \\ \text { Mesic } & 12 \% & 21 \% \\ & & \\ \text { Backyard landscape design } & \text { CC\&Rs } & \text { No CC\&Rs } \\ \text { Desert } & 39 \% & 28 \% \\ \text { Oasis } & 43 \% & 46 \% \\ \text { Mesic } & 18 \% & 26 \%\end{array}$

What type of landscape design motif would homeowners prefer to have?

\begin{tabular}{lll} 
Landscape design & CC\&Rs & No CC\&Rs \\
Desert & $33 \%$ & $27 \%$ \\
Oasis & $48 \%$ & $48 \%$ \\
Mesic & $19 \%$ & $24 \%$ \\
\hline
\end{tabular}

maintenance, (2) landscape aesthetics such as flowering, (3) landscape design, (4) overall greenness, (5) plant growth, (6) water conservation, and (7) other. Homeowners in CC\&R or non-CC\&R neighborhood communities had similar preferences for important landscape traits. The two traits that homeowners considered most important for their landscape were ease of maintenance (64\%) and landscape aesthetics (38\%). Water conservation was third most important (26\%), while landscape design type (22\%) and plant growth habit (19\%) were of less importance. Only 10\% chose overall greenness in the landscape as an important landscape trait.

Vegetation is often the most replicated landscape feature at local scales (Zmyslony and Gagnon 1998). High spatial autocorrelation of residential vegetation, often referred to as landscape mimicry, may be promoted by CC\&Rs that limit homeowner choices of landscape plant materials to only those approved by local governing community associations. We found that around three-fourths of all homeowner respondents believed that their landscapes were similar to those of their neighbors (Table 5). Moreover, 37\% of respondents from neighborhood communities with CC\&Rs believed that their landscapes were very similar to those of their neighbors, compared with only $28 \%$ from homeowners who lived in communities without CC\&Rs. These data suggest that residential landscape mimicry might be confounded by the presence of CC\&Rs.

Table 4. Influence of geographic place of origin in the United States on percentage of survey respondents who indicated a residential landscape preference for desert, oasis, or mesic landscape design motifs in Phoenix, Arizona, metropolitan area.

\begin{tabular}{llcl}
\hline & \multicolumn{3}{c}{ Landscape design } \\
\cline { 2 - 4 } Place of origin & Desert & Oasis & Mesic \\
\hline Northeast & $33 \% \mathrm{y}$ & $51 \%$ & $16 \%$ \\
Southeast & $30 \%$ & $54 \%$ & $16 \%$ \\
Midwest & $33 \%$ & $47 \%$ & $20 \%$ \\
Great Plains & $43 \%$ & $38 \%$ & $19 \%$ \\
Southwest & $21 \%$ & $54 \%$ & $25 \%$ \\
Arizona & $16 \%$ & $50 \%$ & $33 \%$ \\
Pacific West & $33 \%$ & $40 \%$ & $27 \%$ \\
Intermountain & $23 \%$ & $49 \%$ & $28 \%$ \\
\hline
\end{tabular}

${ }^{2}$ Northeast $=$ Delaware, Connecticut, Maine, Maryland, Massachusetts, New Hampshire, New York, Pennsylvania, Rhode Island, Vermont; Southeast = Alabama, Arkansas, Florida, Georgia, Kentucky, Louisiana, Mississippi, North Carolina, South Carolina, Tennessee, Virginia, West Virginia; Midwest = Minnesota, Wisconsin, Iowa, Missouri, Illinois, Indiana, Michigan, Ohio; Great Plains = Kansas, North Dakota, South Dakota, Nebraska; Southwest $=$ New Mexico, Oklahoma, Texas; Intermountain = Colorado, Idaho, Montana, Nevada, Utah, Wyoming; Pacific West = Alaska, California, Hawaii, Oregon, Washington.

'Rows that add up to $<100$ had nearly $1 \%$ "no preference" responses. 


\section{Table 5. Influence of the presence or absence of cov- enants, codes, and restrictions (CC\&Rs) that control landscape activities on residential homeowner land- scape perceptions, preferences, and activities in Phoenix, Arizona.}

Do homeowners hire a local landscape firm to maintain their landscapes?

$\begin{array}{lll}\text { Landscape maintenance } & \text { CC\&R } & \text { No CC\&R } \\ \text { Maintained by landscape firm } & 35 \% & 25 \% \\ \text { Self maintained } & 65 \% & 75 \%\end{array}$

Overall, do homeowners have a preference for landscape appearance?

$\begin{array}{lcl}\text { Landscape appearance } & \text { CC\&R } & \text { No CC\&R } \\ \text { Neat and formal } & 34 \% & 37 \% \\ \text { Natural and informal } & 62 \% & 58 \% \\ \text { Don't care } & 4 \% & 5 \%\end{array}$

Do homeowners perceive that their landscape was similar to their neighbors?

\begin{tabular}{lll} 
Landscape mimicry & CC\&R & No CC\&R \\
Very similar & $37 \%$ & $28 \%$ \\
Similar & $40 \%$ & $43 \%$ \\
Somewhat different & $15 \%$ & $13 \%$ \\
Completely different & $8 \%$ & $16 \%$ \\
\hline
\end{tabular}

\section{CONCLUSION}

New housing developments in the Phoenix metropolitan area are increasingly part of planned communities with governing boards or homeowner associations that use CC\&Rs to control homeowner landscape activities. We found that one of the impacts of CC\&Rs is to shape the contemporary structure and composition of vegetation in residential landscapes in Phoenix in favor of desert landscape design motifs. The focus of this manifestation is the front yard landscape. However, we found a distinct incongruence between the prevalence of desert landscape designs in front yard landscapes and landscape preferences of homeowners in Phoenix. Homeowners more often preferred an oasis landscape design with a mixture of desert-adapted plants, mesic plant species, and turfgrass lawns. These findings reflect the increasing influence and importance of xeric landscape design in the Southwest as a contemporary landscape style in urban areas bridled by an arid climate and suggests that like Tucson, Arizona (McPherson and Haip 1989), the emergent popularity of desert landscaping in Phoenix is predominately a top-down social phenomenon, directed by public and private interest groups for residential homeowner use.

Homeowners who did prefer landscapes with a desert design cited ease of maintenance as the number one reason for that preference, followed by environmental (water conservation) concerns and a sense of desert place. Those who preferred oasis or mesic landscapes cited aesthetics as most important. Homeowners who preferred green in the landscape also stated that it invoked "childhood memories" and a sense that a green environment provides a cool respite from the desert heat. The majority of homeowners who preferred oasis designs were not able to make clear distinctions beyond general landscape aesthetics but cited all other reasons with equal frequency: a reminder of "home," water conservation, a desert sense of place, and green as a cool environment. The mixed oasis landscape is the number one design preference among those surveyed and seems to be mixed for mixed reasons, to cover all bases. In conclusion, findings of this study have begun to elucidate the dichotomy of social issues that shape the horticultural ecology of the Phoenix urban landscape.

\section{LITERATURE CITED}

Anderson, L.M., and H.K. Cordell. 1988. Influence of trees on residential property values in Athens, Georgia (U.S.A.): A survey based on actual sales prices. Landscape Urban Plann. 15:153-164.

Arizona Department of Water Resources. 2002. http:// www.adwr.state.az.us/AZWaterInfo/InsideAMAs/ amaphoenix.html (accessed 11/19/02).

Arizona State University. 2001. Center for Business Research. http://webdev.cob.asu.edu/seid/cbr/popest.pdf (accessed 11/19/02).

Correll, M.R., and J.L. Knetson. 1978. The effects of green belts on residential property values: Some findings on the political economy of open space. Land Econ. 54:207-211.

Dillman, D.A. 1978. Mail and Telephone Surveys. John Wiley and Sons, New York, NY.

Garber, M.P., and K. Bondari. 1995. Landscape installations firms: I. Business characteristics and trends affecting industry performance. J. Environ. Hortic. 13:31-34.

Getz, D.A., A. Karow, and J.J. Kielbaso. 1982. Inner city preferences for trees and urban forest programs. J. Arboric. 8:258-263.

Fry, J., L. Nogue, C. Patterson, and C.S. Smith, 2001. Historic land use phase II. 3rd Annual CAP LTER Research Symposium: 15.

Gober, P.E., E.K. Burns, K. Knowles-Yanez, and J. James. 1998. Rural-to-urban land conversion in metropolitan Phoenix, pp 40-45. In Hall, J.S., N.J. Cayer, and N. Welch. Arizona Policy Choices. Morrison Institute for Public Policy, Arizona State University, Tempe, AZ.

Hardy, J., B.K. Behe, S.S. Barton, T.J. Page, R.E. Schutzki, K. Muzii, R.T. Fernandez, M.T. Haque, J. Booker, C.R. Hall, R. Hinson, P. Knight, R. McNeil, D.B. Rowe, and C. Safley. 2000. Consumers' preferences for plant size, type of plant material and design sophistication in residential landscaping. J. Environ. Hortic. 18:224-230.

Hull, R.B. 1992. How the public values urban forests. J. Arboric. 18:98-101.

Kaplan, R. 1984. The impact of urban nature: A theoretical analysis. Urban Ecol. 8:189-197. 
Maricopa County Tax Assessor. 2002. http://www. maricopa.gov/parcelApplication/default.asp (accessed $11 / 19 / 02$ )

Martin, C.A. 2001. Landscape Water Use in Phoenix, Ariz. Des. Plants 17:26-31.

Martin, C.A., and L.B. Stabler. 2002. Plant gas exchange and water status in urban desert landscapes. J. Arid Environ. 51(2):235-254.

Martin C.A., L.B. Stabler, and A.J. Brazel. 2000. Summer and winter patterns of air temperature and humidity under calm conditions in relation to urban land use. 3rd Symposium on the Urban Environment 3:197-198.

McBride, J.R. 1977. Evaluation of vegetation in environmental planning. Landscape Plann. 4:291-312.

McPherson, E.G. 1994. Using urban forests for energy efficiency and carbon storage. J. For. 92:36-38, 40-41.

_ 1998. Structure and sustainability of Sacramento's urban forest. J. Arboric. 24:174-190.

McPherson, E.G., and R.A. Haip. 1989. Emerging desert landscape in Tucson. Geog. Rev. 79:435-449.

McPherson, E.G., L.P. Herrington, and G.M. Heisler. 1988. Impacts of vegetation on residential heating and cooling. Ener. Build. 12:41-51.

McPherson, E.G., J.R. Simpson, and P.L. Sacamano. 1993. The impact of vegetation on air conditioning and landscape water use in Phoenix. Am. Nurseryman 178(12):165-168.

Motloch, J.L. 1991. An Introduction to Landscape Design. Van Nostrand Reinhold Publishers, New York, NY. 307 pp.

Niemiera, A.X., J. Innis-Smith, and C.E. Leda. 1993. Survey of garden center customer informational and marketing needs. J. Environ. Hortic. 11:25-27.

Nowak, D.J., J.C. Stevens, S.M. Sisinni, and C.J. Luley. 2002. Effects of urban tree management and species selection on atmospheric carbon dioxide. J. Arboric. 28:113-122.

O'Rourke, M.K. 1981. Composition and distribution of urban vegetation in the Tucson basin. J. Arid Environ. 5:235-248.

Rodie, S.N., and E.T. Paprozzi. 1999. Public perceptions of landscape design as a nursery industry service and quality-of-life enhancement factor. J. Environ. Hortic. $17: 18-24$.

Rowntree, R.A., and D.J. Nowak. 1991. Quantifying the role of urban forests in removing atmospheric carbon dioxide. J. Arboric. 17:269-275.

U.S. Census Bureau. 2002a. http://www.census.gov (accessed 11/19/02)

_ . 2002b. http://quickfacts.census.gov/qfd/states/04/ 04013.html (acccessed 1/19/02).

Zmyslony, J., and D. Gagnon. 1998. Residential management of urban front-yard landscape: A random process? Landscape Urban Plann. 40:295-307.
Acknowledgments. This research was funded in part by the International Society of Arboriculture Research Trust John Z. Duling Grant Program and by the National Science Foundation, grant no. DEB-9714833.

${ }^{1 *}$ Urban Horticultural Ecology Research Lab

P.O. Box 871601

Department of Plant Biology

Arizona State University

Tempe, AZ, 85287-1601, U.S.

${ }^{*}$ Corresponding author: Chris A. Martin.

Résumé. Dans la zone métropolitaine de Phoenix en Arizona, les associations communautaires ainsi que les codes, conventions et restrictions légales imposent des limitations aux activités de paysagement dans plusieurs nouveaux quartiers résidentiels. Des études ont été menées dans la région de Phoenix pour développer une compréhension des préférences et pratiques des propriétaires résidentiels en matière de paysagement, et aussi comment ils peuvent être affectés par la législation. Les terrains résidentiels dans les communautés touchées par ces législations ont moins d'arbres, plus d'arbustes et de couvresols, et moins de surface gazonnée que dans les aménagements paysagers des secteurs non affecté par ce type de législations. Plus de propriétaires ont aménagé leur façade sous la forme de déserts que sous celle d'un oasis ou d'un milieu mésique, et ce avec un pourcentage plus élevé pour les propriétaires vivant dans un quartier affecté par ce cadre législatif par rapport à ceux vivant dans un quartier non affecté par ce même cadre. Plus de propriétaires préfèrent un aménagement de type oasis que de type désert ou mésique, et environ $70 \%$ des propriétaires préfèrent un design d'aménagement qui comporte au moins une zone engazonnée. Plus de gens natifs de l'Arizona préfèrent des aménagements de type mésique que les immigrants intérieurs. Les propriétaires ont mentionné comme les deux critères les plus importants pour leur aménagement la facilité d'entretien et l'aspect esthétique. Ces observations reflètent l'influence accrue et l'importance du design d'aménagement de type désertique dans le Sud-ouest comme étant le design de type contemporain dans les zones urbaines confrontées à un climat aride. Ceci suggère que la popularité émergente de l'aménagement désertique à Phoenix est un phénomène social prédominant de haut en bas dirigé par les groupes d'intérêts publics et privés quant à l'utilisation des zones résidentielles privées.

Zusammenfassung. Im Innenstadtbereich von Phoenix, Arizona haben Gemeindeverbände mit der legalen Anwendung von Verordnungen, Regeln und Restriktionen 
(CC\&Rs) in vielen benachbarten Wohngebieten die Landschaftsbauaktivitäten limitiert. In der Gegend von Phoenix wurde eine Studie durchgeführt, um ein Verständnis für Grundstückseigner und ihr Interesse an Landschaftsgestaltung zu entwickeln und um herauszufinden, wie sie durch die CC\&Rs beeinflusst werden. Wohngebiete in Gemeinden mit CC\&Rs hatten weniger Bäume, mehr Büsche und Bodendecker und Gras als Gemeinden ohne CC\&Rs. Viele Hauseigentümer identifizierten ihren Vorgarten eher als eine Wüste statt einer Oase, mit einer wachsenden Prozentzahl Eigentümer, die in Nachbarschaft mit CC\&Rs und weniger ohne CC\&Rs lebten. Mehr Grundstückeigner bevorzugten den Oasentyp gegenüber dem Wüstendesign und ca. 70 \% bevorzugten ein Landschaftsdesign mit zumindest etwas Grünfläche. Viele der Ureinwohner von Arizona bevorzugten gegenüber den Migranten den Mesa-Landschaftsstil. Die Grundstückseigner stellten die Leichtigkeit der Pflege und die ästhetischen Aspekte als die zwei wichtigsten Bereiche bei der Landschaftsgestaltung heraus. Diese Ergebnisse reflektieren den wachsenden Einfluss und die Wichtigkeit von Wüstenlandschaftsdesign im Südwesten der USA als zeitgenössisches Landschaftsdesign in urbanen Gegenden mit aridem Klima und weist darauf hin, dass die neue Popularität von Wüstenlandschaftsdesign in Phoenix im untergeordneten Sinne ein soziales Problem ist, welches durch öffentliche und private Interessensgruppen bei den Grundstückseignern dargestellt wird.

Resumen. En el área metropolitana de Phoenix, Arizona, las asociaciones comunitarias con leyes, códigos y restricciones (CC\&Rs) imponen limitaciones a las actividades en el paisaje en muchas zonas residenciales vecinales. Se condujeron estudios para lograr un entendimiento de las preferencias de los propietarios y de las prácticas, y de cómo se podrían mitigar los impactos por CC\&Rs. Las áreas residencias con restricciones CC\&Rs tenían pocos árboles y más arbustos y otras coberturas del terreno, y menos pasto que los paisajes sin CC\&Rs. Muchos propietarios identificaron sus áreas como desérticas antes que un diseño en oasis, con el porcentaje más alto de propietarios viviendo en áreas con CC\&Rs que en áreas sin CC\&Rs. La mayoría de los propietarios prefirieron un diseño del paisaje tipo oasis y aproximadamente un 70\% prefirieron un terreno que tuviera al menos un área con césped. Los propietarios citaron la facilidad del mantenimiento y la estética como las dos más importantes características de sus paisajes. Estos hallazgos reflejan la influencia y la importancia de los diseños desérticos en la arquitectura del paisaje en el Suroeste, como un estilo contemporáneo en áreas urbanas. 